\title{
Analisis Kandungan Vitamin C Bahan Makanan dan Minuman dengan Metode Iodimetri
}

\author{
${ }^{1}$ Nelius Harefa, ${ }^{2}$ Nella Feronika, ${ }^{3}$ Angel Djara Kana, ${ }^{4}$ Romelia Hutagalung, ${ }^{5}$ Donna \\ Chaterine, ${ }^{6}$ Yongkifianus Bela
}

1, 2, 3,4,5,6 Prodi Studi Pendidikan Kimia, Universitas Kristen Indonesia, Jakarta

Email Korespondensi: nelius.harefa@uki.ac.id

\author{
Article Info \\ Article History \\ Received: 20 February \\ 2020 \\ Revised: 10 March 2020 \\ Published: 25 March 2020 \\ Keywords \\ Iodimetric Method; \\ Vitamin C, Food and \\ Beverage Ingredients
}

\section{Informasi Artikel \\ Sejarah Artikel}

Diterima: 20 Februari 2020

Direvisi: 10 Maret 2020

Dipublikasi: 25 Maret 2020

Kata kunci

Metode Iodimetri; Vitamin

C, Bahan Makanan dan

Minuman

\begin{abstract}
Vitamin $C$ is an essential compound for human. The sources of Vitamin $C$ are very abundant both natural and artificial. In this study, analyzed levels of Vitamin $C$ in natural foods and artificial drinks that can be consumed by human. The analysis aims to provide the information of Vitamin $C$ levels from these foodstuffs and beverages, so that humans can predict the content of Vitamin $C$ that must be consumed. Many methods can be used to determine Vitamin $C$ in a sample, the method used in determining Vitamin $C$ in a research sample is the iodimetric method. Based on the analysis of research data, sample A was 2.286 $\mathrm{mg} / \mathrm{g}$, sample B was $2.204 \mathrm{mg} / \mathrm{g}$, sample C was $0.044 \mathrm{mg} / \mathrm{g}$. The data shows that human need about 18 - 68 grams of sample A material per day to fulfill 40 - 90 mg of Vitamin C needed. Sample B material it was needed around 20 - 70 grams to fulfill 40 - $90 \mathrm{mg}$ of Vitamin $C$ needed. And, the sample $C$ material is needed around 56 - 106 grams per day to fulfill 40 - $90 \mathrm{mg}$ of Vitamin C needed.
\end{abstract}

\section{Abstrak}

Vitamin C merupakan senyawa esensial bagi tubuh manusia. Sumber Vitamin C sangat melimpah baik yang alami maupun buatan. Pada penelitian, dianalisis kadar Vitamin C pada bahan makanan alami dan minuman buatan yang dapat dikonsumsi manusia. Analisis bertujuan memberikan informasi kadar Vitamin C dari bahan makanan dan minuman tersebut, sehingga manusia dapat memprediksi kandungan Vitamin $C$ yang harus dikonsumsi maupun yang telah dikonsumsi setiap harinya. Banyak metode yang dapat digunakan untuk menentukan Vitamin $C$ dalam suatu sampel, metode yang digunakan pada penentuan Vitamin $C$ pada sampel penelitian yakni metode iodimetri. Berdasarkan analisis data penelitian, kadar Vitamin C pada sampel A sebesar $2,286 \mathrm{mg} / \mathrm{g}$ sampel, kadar Vitamin C sampel B sebesar 2,204 mg/g sampel, dan kadar Vitamin C pada sampel C sebesar 0,044 mg/g sampel. Data tersebut menunjukkan bahwa manusia membutuhkan sekitar 18 - 68 gram bahan sampel A perhari untuk memenuhi 40 - 90 mg Vitamin C yang dibutuhkan. Bahan sampel B dibutuhkan sekitar 20 - 70 gram untuk memenuhi 40 - 90 mg Vitamin $C$ yang dibutuhkan. Bahan sampel C dibutuhkan sekitar sekitar $56-106$ gram perhari untuk memenuhi 40 - $90 \mathrm{mg}$ Vitamin C yang dibutuhkan.

Sitasi: Harefa, Nelius., Feronika, Nella., Kana A. D., Hutagalung, R., Chaterine, D., \& Bela, Yongkifianus. (2020). Analisis Kandungan Vitamin C Bahan Makanan dan Minuman dengan Metode Iodimetri. Science Education and Application Journal. 2(1) 35-42.

\section{PENDAHULUAN}

Vitamin $C$ merupakan senyawa esensial bagi tubuh manusia yang sumbernya melimpah baik yang alami maupun buatan. Sebagian besar sumber Vitamin $C$ merupakan bahan yang dapat dikonsumsi manusia, dapat ditemukan ditempat umum seperti pasar, swalayan, dan sebagainya. Sumber Vitamin C dapat berupa buah-buahan, sayur-sayuran, ikan, dan beberapa produk olahan lainnya. Lestari (2019), memaparkan bahwa buah buni hitam dan buah buni 
merah merupakan salah satu buah penghasil Vitamin C. Kedua buah ini mengandung 0,43\% dan $0,31 \%$ Vitamin $\mathrm{C}$, kadar tersebut tergolong kategori tinggi.

Daun kaktus juga merupakan salah satu penghasil Vitamin $\mathrm{C}$ alami yang dapat dijadikan sayur olahan atau dikonsumsi secara langsung. Kadar Vitamin C daun Kaktus sebelum dimasak lebih tinggi dibanding kandungan Vitamin $\mathrm{C}$ setelah diolah, walaupun demikian daun kaktus olahan tetap mengandung vitamin C yang tinggi (Sulhan, 2019). Maulana, dkk (2019) memaparkan bahwa buah delima merah dan daging delima merupakan sumber Vitamin $\mathrm{C}$ alami yang dapat dikonsumsi manusia. Buah delima merah mengandung Vitamin C lebih tinggi dibanding daging buah delima putih. Tahir, Kusuma, \& Ekawati (2018), memaparkan bahwa jeruk pamelo merupakan sumber vitamin $\mathrm{C}$ alami yang baik dikonsumsi oleh manusia. Kandungan vitamin $\mathrm{C}$ jeruk pamelo varietas daging merah lebih tinggi dibanding varietas daging putih.

Buah naga merah merupakan salah satu sumber vitamin $\mathrm{C}$ alami yang dapat dikonsumsi baik daging maupun kulitnya. Kandungan vitamin $C$ daging buah naga merah lebih tinggi dibanding kulit buah naga merah (Syarifuddin, et al., 2019). Selain itu, buah jambu biji merah (Maliku, 2019); buah kelengkeng (Riandini, 2019); buah ara dan buah markisa hutan (Ngginak, Rupidara, \& Daud, 2019); buah kiwi (Mulyani, 2018); buah naga putih (Suhaera, et al., 2018); Cabai keriting merah, cabai rawit hijau, dan cabai rawit hijau besar (Tambunan, dkk., 2018). Selain buah-buahan, jenis sayuran seperti sayuran sawi juga termasuk sumber vitamin C alami yang dapat dikonsumsi manusia (Irayani \& Nugrahani, 2016). Selain itu, beberapa jenis ikan juga dapat dijadikan sebagai sumber vitamin $C$ walau pada konsentrasi rendah (Aisyi, et al., 2019). Bahkan, beberapa jenis mikroalga juga termasuk penghasil vitamin $C$ alami yang dapat dijadikan oleh manusia sebagai sumber pemenuhan kebutuhan akan vitamin C (Setiawati \& Sari, 2017).

Namun, kadar Vitamin C sangat dipengaruhi oleh perlakuan yang diberikan selain jenis bahan yang menjadi sumber Vitamin C (Irjayanti, Budiman, \& Baculu, 2018). Putri \& Setiawati (2017), memaparkan bahwa kandungan Vitamin C buah nanas segar lebih tinggi dibanding buah nanas yang sudah diolah menjadi produk kalengan. Penyimpanan bahan sumber Vitamin $\mathrm{C}$ juga berpengaruh terhadap kadar Vitamin $\mathrm{C}$, semakin lama bahan sumber Vitamin $\mathrm{C}$ disimpan maka kadar Vitamin $\mathrm{C}$ dalam bahan tersebut akan semakin menurun (Rahim \& Alimuddin, 2016); (Maajid, Sunarmi, \& Kirwanto, 2018). Perlakuan berupa evaporasi (Nisa, 2018) dan fermentasi dapat mempengaruhi kadar Vitamin C, lama fermentasi akan menghasilkan Vitamin $\mathrm{C}$ yang optimum pada lama waktu fermentasi yang sesuai (Puspitasari, Palupi, \& Nurikasari, 2017).

Kandungan Vitamin $\mathrm{C}$ dari bahan makanan maupun minuman yang menjadi sumber Vitamin $\mathrm{C}$ perlu diketahui oleh masyarakat sehingga masyarakat dapat memprediksi kebutuhannya akan Vitamin C. Oleh sebab itu, diperlukan analisis baik berupa analisis konvensional maupun analisis modern. Analisis konvensional seperti metode iodimetri dapat digunakan untuk menganalisis kadar Vitamin C dalam sampel bahan makanan maupun minuman (Damayanti \& Kurniawati, 2017); (Nurjannah, Sabang, \& Afadil, 2018). Analisis modern seperti pemanfaatan spektrofotometri UV-Vis dapat digunakan untuk menganalisis kadar Vitamin C suatu sampel (Tahir, Hikmah, \& Rahmawati, 2016).

\section{METODE}

Penelitian dilakukan di laboratorium kimia Universitas Kristen Indonesia pada Oktober 2019. Sampel penelitian merupakan bahan makanan yang biasa dikonsumsi masyarakat sehari-hari dan diyakini mengandung Vitamin $\mathrm{C}$ yakni buah nanas, minuman kemasan, dan cabai merah. 
Pada sampel dilakukan analisis Vitamin $\mathrm{C}$ dengan metode iodimetri dengan alur penelitian seperti Gambar 1

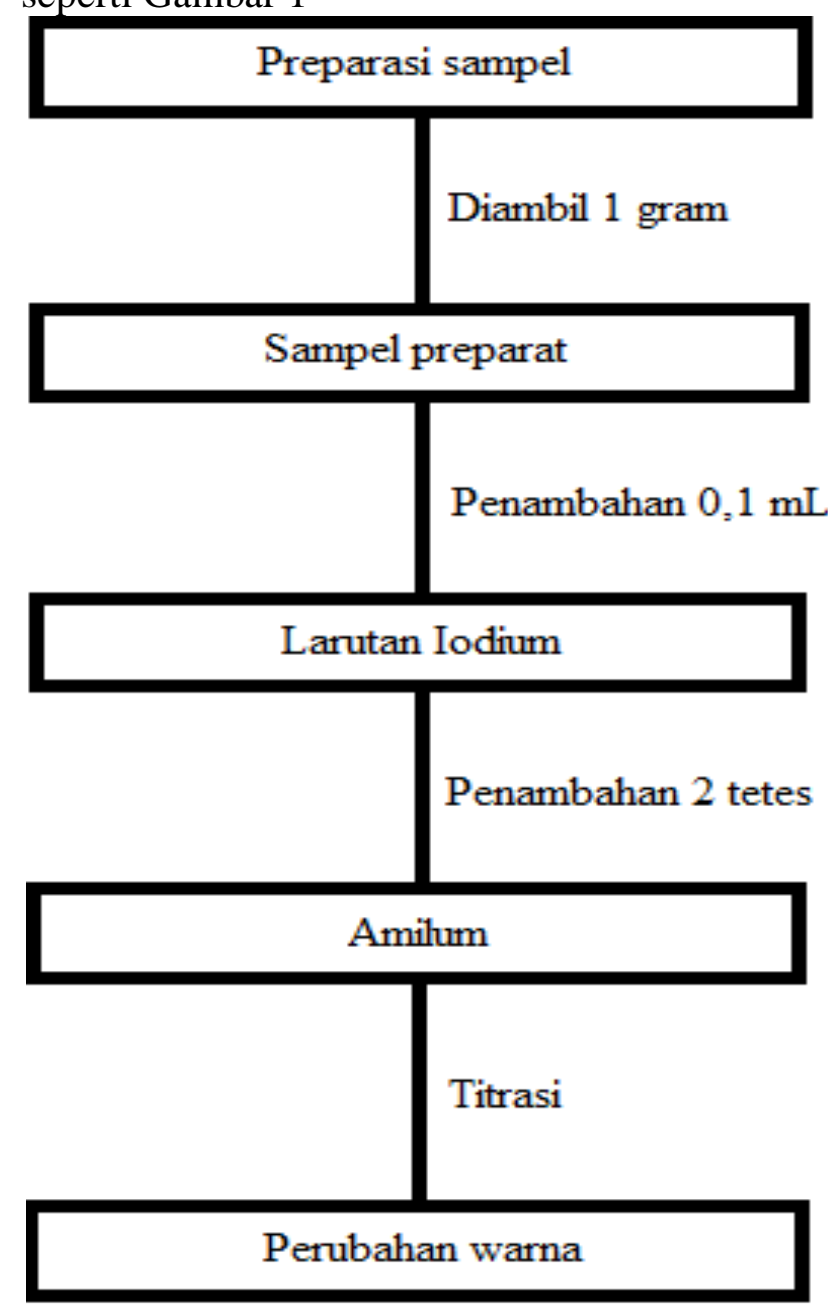

Gambar 1. Diagram Alir Penelitian

Vitamin C merupakan salah satu vitamin esensial bagi tubuh manusia yang pemenuhannya dapat dilakukan dengan mengkonsumsi bahan makanan yang mengadung Vitamin C. Untuk mengetahui kadar vitamin C suatu bahan makanan, perlu dilakukan analisis baik analisis modern maupun analisis konvensional. Salah satu analisis konvensional yang dapat digunakan untuk menganalisis kadar vitamin $\mathrm{C}$ bahan makanan dan minuman adalah metode iodometri. Berdasarkan gambar 1, dilakukan analisis kadar vitamin $\mathrm{C}$ buah nanas, minuman kemasan, dan cabai merah dengan metode iodometri.

Langkah pertama, dilakukan preparasi sampel. Buah nanas dan cabai merah dibersihkan dari pengotor, kemudian dihancurkan menggunakan alu. Sampel yang telah hancur kemudian disaring untuk dipisahkan dari filtrat dan residu. Filtrat dari buah nanas dan cabai merah serta sampel minuman diambil masing-masing sebanyak 1 gram dan ditempatkan ke dalam Erlenmeyer berbeda. Langkah berikutnya, ditambahkan larutan iodium sebanyak $0,1 \mathrm{~mL}$ pada masing-masing sampel preparat. Ditempat lain, dirancang alat titrasi dengan larutan iodin sebagai pentiter sebanyak $50 \mathrm{~mL}$. Langkah berikutnya, dilakukan penambahan 2 tetes larutan amilum pada masing-masing sampel preparat. Langkah berikutnya, dilakukan titrasi pada sampel preparat hingga terjadi perubahan warna. Setelah titik akhir titrasi tercapai, volume 
larutan pentiter yang terpakai dicatat dan dianalisis untuk masing-masing sampel. Langkah akhir, dilakukan olah data hasil penelitian untuk mendapatkan kadar vitamin $\mathrm{C}$ pada sampel.

\section{HASIL DAN PEMBAHASAN}

Vitamin $C$ merupakan suplemen bagi tubuh manusia yang dapat diperoleh dari bahan makanan dan minuman. Oleh sebab itu, dibutuhkan analisis kadar Vitamin $\mathrm{C}$ pada bahan makanan dan minuman yang diyakini masyarakat mengandung Vitamin $\mathrm{C}$ yakni buah nanas, minuman kemasan, dan cabai merah. Analisis demikian sangat penting dilakukan agar masyarakat mendapatkan informasi yang valid terhadap kadar Vitamin $\mathrm{C}$ pada berbagai bahan makanan tersebut, sehingga masyarakat dapat memprediksi jumlah makanan dan/atau minuman yang harus dikonsumsi untuk memenuhi kadar Vitamin $\mathrm{C}$ yang diperlukan tubuh. Pada penelitian ini, dilakukan analisis kadar Vitamin $\mathrm{C}$ dari beberapa bahan makanan dan minuman dengan metode iodimetri seperti pada Tabel 1 .

Tabel 1. Kadar Vitamin C Bahan Makanan

\begin{tabular}{lccc}
\hline No. & $\begin{array}{c}\text { Bahan } \\
\text { Makanan/minuman }\end{array}$ & Massa Bahan Makanan/minuman & Kadar Vitamin C \\
\hline 1. & A & 1 gram & $2,286 \mathrm{mg}$ \\
2. & B & 1 gram & $2,204 \mathrm{mg}$ \\
3. & C & 1 gram & $0,044 \mathrm{mg}$ \\
\hline
\end{tabular}

Berdasarkan Tabel 1 di atas, bahan makanan A (buah nanas) mengandung 2,286 mg Vitamin $C$ dalam 1 gram sampel. Data tersebut menunjukkan bahwa manusia membutuhkan sekitar 18 - 68 gram buah nanas perhari untuk memenuhi 40 - $90 \mathrm{mg}$ Vitamin $\mathrm{C}$ yang dibutuhkan. Bahan minuman B (minuman kemasan) mengandung 2,204 mg Vitamin C dalam 1 gram sampel. Data tersebut menunjukkan bahwa manusia membutuhkan sekitar $20-70$ gram bahan minuman B perhari untuk memenuhi $40-90 \mathrm{mg}$ Vitamin $\mathrm{C}$ yang dibutuhkan. Bahan makanan C (Cabai merah) mengandung 0,044 mg Vitamin $C$ dalam 1 gram sampel. Data tersebut menunjukkan bahwa manusia membutuhkan sekitar 56 - 106 gram cabai merah perhari untuk memenuhi 40 - 90 mg Vitamin C yang dibutuhkan. Perbandingan kadar Vitamin $\mathrm{C}$ dari beberapa bahan makanan dan minuman yang menjadi sampel penelitian ditujukan pada Gambar 2.

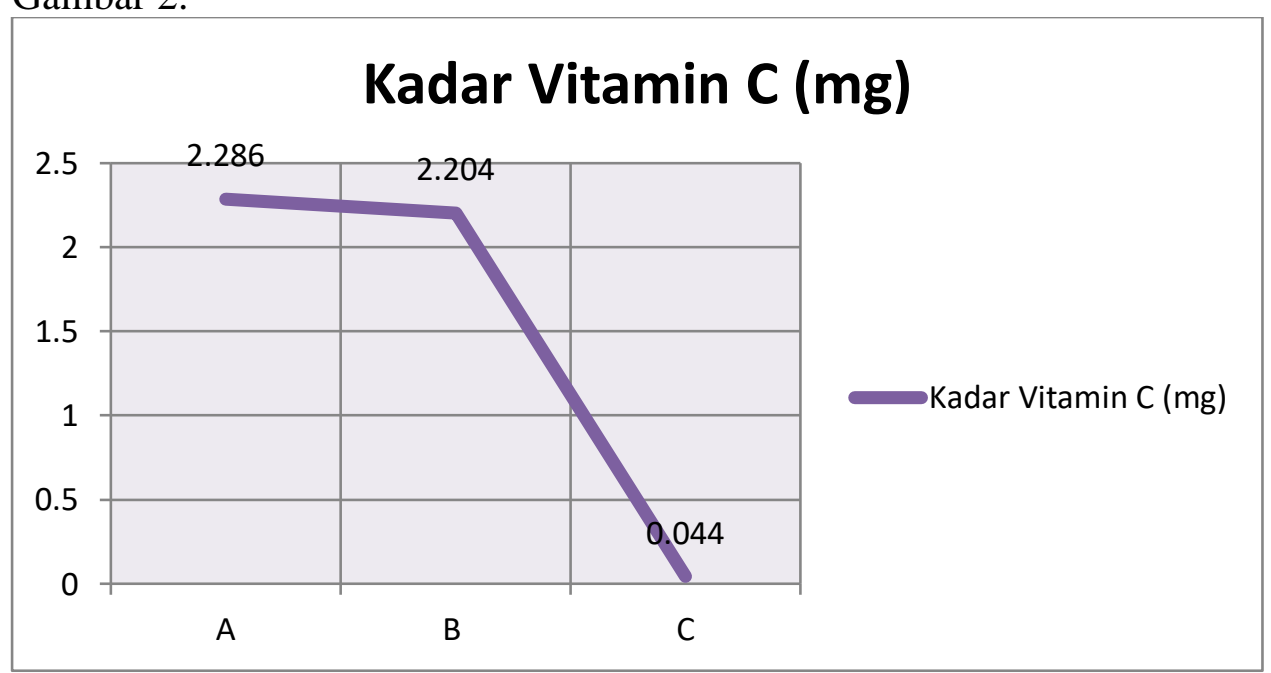

Gambar 2. Perbandingan Kadar Vitamin C Bahan Makanan dan Minuman 
Berdasarkan Gambar 2 di atas, bahan makanan A mengandung Vitamin $\mathrm{C}$ tertinggi dibanding dua sampel lainnya. Bahan makanan A (buah nanas) telah dikenal masyarakat sebagai salah satu penghasil Vitamin C. Buah nanas merupakan bahan makanan yang direkomendasikan untuk dikonsumsi masyarakat dalam upaya memenuhi kadar Vitamin $\mathrm{C}$ tubuh. Pemenuhan Vitamin $\mathrm{C}$ dengan mengkonsumsi buah nanas merupakan metode konvensional yang minim dampak negatif kecuali bagi mereka yang dilarang dokter karena penyakit tertentu. Buah nanas tidak mengandung pewarna, pemanis, dan pengawet buatan sehingga dampak negatifnya tergolong minim.

Bahan minuman B (minuman kemasan) merupakan sampel dengan kadar Vitamin $\mathrm{C}$ tertinggi kedua. Sampel ini dapat dikonsumsi sebagai sumber Vitamin C oleh manusia, namun tidak direkomendasikan untuk dikonsumsi secara terus menerus. Vitamin $\mathrm{C}$ dalam sampel ini merupakan Vitamin $\mathrm{C}$ hasil olahan dengan komposisi yang menyerupai komposisi dasar. Vitamin $\mathrm{C}$ hasil olahan tersebut sangat rentan terhadap cuaca, suhu, sinar matahari, dan gangguan-gangguan lainnya seperti bau menyengat yang dapat menyebabkan perubahan struktur dan komposisi Vitamin C. Perubahan komposisi dan struktur Vitamin C, akan berdampak negatif terhadap tubuh manusia. Selain itu, minuman kemasan cenderung mengandung pewarna, pemanis, atau pengawet. Kandungan lain seperti pemanis, pengawet, atau pewarna tersebut justru sangat berbahaya bagi manusia terutama jika dikonsumsi terus menerus. Pemanis, pewarna, atau pengawet umumnya akan menjadi logam berat yang dapat merusak jaringan tubuh manusia (Harefa, 2018); (Harefa, 2019).

Bahan makanan C (cabai) merupakan bahan makanan dengan kandungan terendah dibanding bahan makanan dan bahan minuman yang menjadi sampel pada penelitian. Sampel ini merupakan salah satu bahan makanan alami yang paling efektif untuk dijadikan sumber Vitamin $\mathrm{C}$ tubuh manusia. Bahan makanan ini merupakan penyedap rasa alami, dimana sebagian besar makanan mengandung cabai sebagai penyedap. Artinya, cabai menjadi sumber Vitamin $\mathrm{C}$ akumulatif yang efektif untuk memenuhi kebutuhan akan Vitamin $\mathrm{C}$.

Usaha pemenuhan Vitamin $\mathrm{C}$ tubuh manusia dapat dilakukan dengan sistem akumulasi. Artinya, manusia dapat mengkonsumsi beberapa bahan makanan dan/atau bahan minuman untuk memenuhi kadar Vitamin C. Dengan demikian, pemenuhan kadar Vitamin C dalam tubuh manusia tidak tergantung pada satu jenis bahan makanan atau minuman saja.

Selain bahan makanan dan minuman yang menjadi sampel penelitian, terdapat banyak bahan makanan dan minuman yang mengandung Vitamin $C$ dan dapat dikonsumsi masyarakat dalam upaya pemenuhan kebutuhan Vitamin C. Lestari (2019), memaparkan bahwa buah buni hitam dan buah buni merah merupakan salah satu buah penghasil Vitamin C. Kedua buah ini mengandung 0,43\% dan 0,31\% Vitamin $\mathrm{C}$, kadar tersebut tergolong kategori tinggi.

Daun kaktus juga merupakan salah satu penghasil Vitamin $\mathrm{C}$ alami yang dapat dikonsumsi oleh manusia untuk memenuhi Vitamin C tubuhnya (Sulhan, 2019). Daun kaktus ini dapat dijadikan sayur (dimasak sebelum dikonsumsi) atau dikonsumsi secara langsung sebagai sumber Vitamin C, walaupun kadar Vitamin C daun Kaktus sebelum dimasak lebih tinggi dibanding kandungan Vitamin $\mathrm{C}$ setelah dimasak namun daun ini tetap mengandung Vitamin C yang tinggi. Maulana, dkk (2019), memaparkan bahwa buah delima merah dan daging delima merupakan sumber Vitamin $C$ alami yang dapat dikonsumsi manusia. Buah delima merah mengandung Vitamin $\mathrm{C}$ lebih tinggi dibanding daging buah delima. Tahir, Kusuma, \& Ekawati (2018), memaparkan bahwa jeruk pamelo merupakan sumber Vitamin C alami yang baik dikonsumsi oleh manusia. Kandungan Vitamin $\mathrm{C}$ jeruk pamelo varietas daging merah lebih tinggi dibanding varietas daging putih.

Buah naga merah merupakan salah satu sumber Vitamin $\mathrm{C}$ alami yang dapat dikonsumsi baik daging maupun kulitnya. Kandungan Vitamin $\mathrm{C}$ daging buah naga merah lebih tinggi 
dibanding kulit buah naga merah (Syarifuddin, Zantrie, \& Marbun, 2019). Selain itu, buah jambu biji merah (Maliku, 2019); buah kelengkeng (Riandini, 2019); buah ara dan buah markisa hutan (Ngginak, Rupidara, \& Daud, 2019); buah kiwi (Mulyani, 2018); buah naga putih (Suhaera, Sammulia, \& Islamiah, 2018); Cabai keriting merah, cabai rawit hijau, dan cabai rawit hijau besar (Tambunan, dkk., 2018).

Selain buah-buahan, jenis sayuran seperti sayuran sawi juga termasuk sumber Vitamin $C$ alami yang dapat dikonsumsi manusia (Irayani \& Nugrahani, 2016). Selain itu, beberapa jenis ikan juga dapat dijadikan sebagai sumber Vitamin $\mathrm{C}$ walau pada konsentrasi rendah (Aisyi, Santoso, \& Lisminingsih, 2019). Bahkan, beberapa jenis mikroalga juga termasuk penghasil Vitamin C alami yang dapat dijadikan oleh manusia sebagai sumber pemenuhan kebutuhan akan Vitamin C (Setiawati \& Sari, 2017). Oleh sebab itu, kekurangan Vitamin C semestinya bukan menjadi masalah buat kehidupan manusia, karena sumber Vitamin $C$ sejatinya begitu melimpah baik yang alami maupun buatan.

\section{KESIMPULAN}

Berdasarkan hasil penelitian, sampel A mengandung 2,286 mg/g vitamin C, maka manusia membutuhkan $18-68$ gram/hari sampel A untuk memenuhi kebutuhan vitamin $\mathrm{C}$ ideal. Sampel B mengandung 2,204 mg/g vitamin C, maka manusia membutuhkan $20-70 \mathrm{gram} / \mathrm{hari}$ sampel B untuk memenuhi kebutuhan vitamin C ideal. Sampel C mengandung 0,044 mg/g vitamin $\mathrm{C}$, maka manusia membutuhkan 56 - 106 gram/hari sampel $\mathrm{C}$ untuk memenuhi kebutuhan Vitamin C ideal. Pemenuhan Vitamin C melalui konsumsi bahan makanan dan minuman dapat dilakukan dengan pengakumulasian.

\section{SARAN}

Vitamin C merupakan vitamin esensial bagi tubuh manusia. Vitamin C merupakan salah satu vitamin yang pemenuhannya dapat dilakukan dengan mudah, karena sumber Vitamin $\mathrm{C}$ tersedia dari bahan makanan dan/atau minuman yang dikonsumsi manusia. Namun, penting dilakukan analisis kandungan Vitamin $\mathrm{C}$ dari bahan makanan dan minuman tersebut baik dari segi variasi faktor degradasi Vitamin $\mathrm{C}$ maupun penggunaan alat analisis mutakhir dan modern agar ketersediaan informasi kandungan Vitamin $\mathrm{C}$ dari berbagai bahan makanan dan minuman lebih komprehensif. Dengan demikian, masyarakat dapat memprediksi kebutuhannya akan Vitamin $\mathrm{C}$ serta bahan makanan dan/atau minuman yang dibutuhkan untuk memenuhinya

\section{DAFTAR PUSTAKA}

Aisyi, D. R., Santoso, H., \& Lisminingsih, R. D. (2019). analisis kadar protein dan vitamin c pada sambal-ikan sebelum dan sesudah diolah. Jurnal SAINS ALAMI (Known Nature), 2(1). DOI: $10.33474 /$ j.sa.v2i1.2957

Asmal, A. (2018). Analisis Kandungan Vitamin C Dalam Cabai Rawit (Capsicum fructuscens L.) Secara Iodimetri. Jurnal Farmasi Sandi Karsa, 4(7), 99-103.

Damayanti, E. T., \& Kurniawati, P. (2017, November). Perbandingan Metode Penentuan Vitamin C pada Minuman Kemasan Menggunakan Metode Spektrofotometer UV-Vis dan Iodimetri. In dalam Seminar Nasoinal Kimia dan Pembelajarannya, Malang.

Harefa, N. (2018). Sensitivitas Ligan Ditizon terhadap Absorbsi Logam Zink dengan Teknik Emulsi Membran Cair. EduMatSains: Jurnal Pendidikan, Matematika dan Sains, 3(1), 57-68. 
Harefa, N., Tafonao, G. S., \& Sinaga, D. L. (2019). Efektivitas Tawas Hasil Olahan Limbah Aluminium Terhadap Penyerapan Logam Alkali Tanah dengan Metode Gravimetri. EduMatSains: Jurnal Pendidikan, Matematika dan Sains, 4(1), 65-76.

Iriyani, D., \& Nugrahani, P. (2016). Status Kandungan Vitamin C Beberapa Sayuran Daun Hasil Budidaya Pertanian Perkotaan di Surabaya. PLUMULA Berkala Ilmiah AgroTeknologi, 5(2), 161-167.

Irjayanti, L., Budiman, B., \& Baculu, E. P. H. (2018). ANALISIS KANDUNGAN VITAMIN A DAN C KERIPIK NANGKA (Artocarpus heterophyllus 1.) PRODUKSI INDUSTRI RUMAH TANGGA DI KABUPATEN TOLITOLI. Jurnal Kolaboratif Sains, 1(1). DOI: 10.31934/jom.v1i1.346

Lestari, A. A. (2019, August). ANALISIS KADAR ANTOSIANIN DAN VITAMIN C SERTA DAYA TERIMA KONSUMEN SIRUP BUAH BUNI. In Prosiding Seminar Nasional Inovasi Teknologi Hasil Perkebunan (Vol. 1, No. 1, pp. 159-166).

Maajid, L. A., Sunarmi, S., \& Kirwanto, A. (2018). PENGARUH LAMA PENYIMPANAN TERHADAP KADAR VITAMIN C BUAH APEL (Malus sylvestris Mill.). JURNAL KEBIDANAN DAN KESEHATAN TRADISIONAL, 3(2).

Maliku, R. M. (2019). PENETAPAN KADAR VITAMIN C PADA BUAH JAMBU BIJI MERAH (Psidium guajava L.) DENGAN METODE TITRASI NA-2, 6 DICHLOROPHENOL INDOPHENOL (DCIP). Media Farmasi, 13(2), 30-35. DOI: 10.32382/mf.v13i2.879

Maulana, A., Abidin, Z., Sadjidin, S., \& Naid, T. (2019). Analysis Of Vitamin C Level In Red And White Pepper (Punica granatum L.) Fruit Spectrophotometry UV-VIS. Window of Health: Jurnal Kesehatan, 155-161. DOI: 10.33368/woh.v0i0.168

Mulyani, E. (2018). Perbandingan Hasil Penetapan Kadar Vitamin C pada Buah Kiwi (Actinidia deliciousa) dengan Menggunakan Metode Iodimetri dan Spektrofotometri UV-Vis. Pharmauho: Jurnal Farmasi, Sains, dan Kesehatan, 3(2). DOI: 10.33772/pharmauho.v3i2.3535

Ngginak, J., Rupidara, A., \& Daud, Y. (2019). Analisis Kandungan Vitamin C dari Ekstrak Buah Ara (Ficus carica L) dan Markisa Hutan (Passiflora foetida L). Jurnal Sains dan Edukasi Sains, 2(2), 54-59. DOI: 10.24246/juses.v2i2p54-59

Nisa, Q. A. Y. K. (2018). ANALISIS OPTIMASI KADAR VITAMIN C DARI FILTRAT BUAH NANAS (Ananas comosus L Merr) MENGGUNAKAN SISTEM EVAPORATOR VACUUM. Jurnal Inovasi Teknik Kimia, 3(2). DOI: 10.31942/inteka.v3i2.2490

Nurjannah, I., Sabang, S. M., \& Afadil, A. (2018). Analisis Kadar Vitamin C, Kalsium dan Posforus pada Cabai Rawit (Capsicum frustescens L.) Hasil Pengawetan. Jurnal Akademika Kimia, 7(4), 185-188.

Puspitasari, Y., Palupi, R., \& Nurikasari, M. (2017). Analisis kandungan vitamin C teh kombucha berdasarkan lama fermentasi sebagai alternatif minuman untuk antioksidan. GLOBAL HEALTH SCIENCE (GHS), 2(3), 245-253. DOI: 10.33846/ghs.v2i3.137

Putri, M. P., \& Setiawati, Y. H. (2017). Analisis kadar vitamin C pada buah nanas segar (Ananas comosus (L.) Merr) dan buah nanas kaleng dengan metode spektrofotometri UV-Vis. Jurnal Wiyata: Penelitian Sains dan Kesehatan, 2(1), 34-38.

Rahim, A., \& Alimuddin, A. (2016). Analisis Kandungan Asam Askorbat Dalam Buah Naga Merah (Hylocereus polyrhizus) Dengan Iodimetri. Jurnal Kimia Mulawarman, 14(1).

Riandini, H. M. (2019). Analisis Kadar Vitamin C Pada Daging Buah Kelengkeng (Dimocarpus longan L) Segar dan Daging Buah Kelengkeng Kaleng Dengan Metode 
Spektrofotometri UV-Vis. J-HESTECH (Journal Of Health Educational Science And Technology), 2(2), 119-126. DOI: 10.25139/htc.v2i2.2068

Setiawati, T., \& Sari, M. (2017). Analisis Kandungan Vitamin C Makroalga serta Potensinya bagi Masyarakat di Kawasan Pantai Timur Cagar Alam Pananjung Pangandaran. JURNAL ISTEK, 10(2).

Septaria, K., Dewanti, B. A., \& Habibbulloh, M. (2019). Implementasi Metode Pembelajaran Spot Capturing Pada Materi Pemanasan Global untuk Meningkatkan Keterampilan Proses Sains. Prisma Sains: Jurnal Pengkajian Ilmu dan Pembelajaran Matematika dan IPA IKIP Mataram, 7(1), 27-37.

Suhaera, S., Sammulia, S. F., \& Islamiah, H. (2019). Analisis Kadar Vitamin C pada Buah Naga Merah (Hylocereus lemairei (Hook.) Britton \& Rose) dan Buah Naga Putih (Hylocereus undatus (Haw.) Britton \& Rose) di Kepulauan Riau menggunakan Spektrofotometri Ultraviolet. PHARMACY: Jurnal Farmasi Indonesia (Pharmaceutical Journal of Indonesia), 16(1), 146-152. DOI: 10.30595/pharmacy.v16i1.4579

Sulhan, M. H. S. H. (2019). Analisis Kadar Vitamin C Pada Daun Katuk (Sauropus Androgynus) Segar, Direbus dan Dikukus Dengan Metode Spektrofotometri UV-Vis. Jurnal Medika Cendikia, 6(01), 55-63. DOI: 10.33482/medika.v6i01.102

Syarifuddin, A. N., Zantrie, R., \& Marbun, R. A. T. (2019). IDENTIFIKASI KADAR VITAMIN C PADA DAGING DAN KULIT BUAH NAGA MERAH (HYLOCEREUS POLYRHIZUS) DENGAN METODE SPEKTROFOTOMETRI UV-VISIBLE. JURNAL FARMASIMED (JFM), 2(1), 40-46. DOI: 10.35451/jfm.v2i1.285

Tahir, M., Hikmah, N., \& Rahmawati, R. (2016). Analisis Kandungan Vitamin C dan $\beta$ Karoten dalam Daun Kelor (Moringa Oleifra Lam.) dengan Metode Spektrofotometri Uv-vis. Jurnal Fitofarmaka Indonesia, 3(1), 135-140. DOI: 10.33096/jffi.v3i1.173

Tahir, M., Kusuma, A. T., \& Ekawati, E. (2018). Analysis of Lycopene and Vitamin C Levels of Pomelo Citrus Fruit (Citrus maxima (Burm) Merr) Red n White Varieties From South Sulawesi. JCPS (Journal of Current Pharmaceutical Sciences), 2(1), 125-130.

Tambunan, L. R., Ningsih, W., Ayu, N. P., \& Nanda, H. (2018). PENENTUAN KADAR VITAMIN C BEBERAPA JENIS CABAI (Capsicum sp.) DENGAN SPEKTROFOTOMETRI UV-VIS. Jurnal Kimia Riset, 3(1), 1-5. DOI: $\underline{10.20473 / \mathrm{jkr} . v 3 \mathrm{i} 1.8874}$ 